\title{
Occurrence of fungal diseases caused by fungi on faba bean (Vicia faba L. var. minor Harz.) plants in different regions of Poland
}

\section{Występowanie chorób powodowanych przez grzyby na roślinach bobiku (Vicia faba L. var. minor Harz.) w różnych rejonach Polski}

\author{
Janusz Podleśny ${ }^{1 *}$, Anna Podleśna ${ }^{1}$, Michał Nędzi ${ }^{2}$
}

\begin{abstract}
Summary
The aim of the study was to evaluate the degree of faba bean (Vicia faba L. var. minor Harz.) infection by pathogens, in different regions of Poland, in dependence on cultivar and course of weather conditions. The experiments were conducted at the Experimental Stations of Research Centre for Cultivar Testing (COBORU), located in the following voivodeships: opolskie, pomorskie, śląskie, podkarpackie, pomorskie, zachodniopomorskie, warmińsko-mazurskie and dolnośląskie. The research included 9 cultivars of faba bean from the Polish National List of Agricultural Plant Varieties. Differentiated occurrence of faba bean diseases was recorded in the particular regions of Poland. Ascochyta blight (Ascochyta fabae Speg.) and chocolate spot (Botrytis fabae Sardina) occurred at the greatest severity, while faba bean rust [Uromyces fabae (Pers). J. Schröt.] infection was observed at considerably lower degree. Not too much difference in resistance of faba bean cultivars to diseases was revealed in the study. There was a correlation between diseases development and course of weather condition as well as between plant infection by pathogens and faba bean yielding.
\end{abstract}

Key words: faba bean; cultivar; pathogen; region of Poland; yield

\section{Streszczenie}

Celem badań była ocena stopnia porażenia roślin bobiku (Vicia faba L. var. minor Harz.) przez patogeny, w różnych rejonach Polski, w zależności od uprawianej odmiany oraz przebiegu warunków pogodowych. Doświadczenia prowadzono w Stacjach Oceny Odmian Centralnego Ośrodka Badania Odmian Roślin Uprawnych (COBORU), zlokalizowanych w następujących województwach: opolskie, pomorskie, śląskie, podkarpackie, pomorskie, zachodniopomorskie, warmińsko-mazurskie i dolnośląskie. W badaniach uwzględniono 9 odmian bobiku wpisanych na Listę Odmian Roślin Rolniczych. Stwierdzono zróżnicowane występowanie chorób na roślinach bobiku w poszczególnych rejonach Polski. W największym nasileniu występowały askochytoza (Ascochyta fabae Speg.) i czekoladowa plamistość bobiku (Botrytis fabae Sardina), natomiast w znacznie mniejszym - rdza bobiku [Uromyces fabae (Pers). J. Schröt.]. Wykazano niezbyt duże różnice w odporności odmian bobiku na choroby. Stwierdzono zależności między rozwojem chorób a przebiegiem warunków pogodowych oraz między porażeniem roślin przez patogeny a plonowaniem bobiku.

Słowa kluczowe: bobik; odmiana; patogen; region Polski; plon

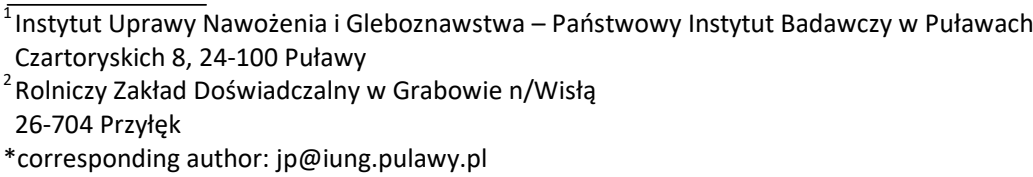




\section{Wstęp / Introduction}

W ostatnich latach zwiększa się w Polsce zainteresowanie uprawą roślin strączkowych, w tym także bobiku (Osiecka 2016). Jest to spowodowane przede wszystkim zwiększeniem opłacalności produkcji wynikającej z wprowadzenia specjalnych dopłat do ich uprawy (Jerzak 2014). Ponadto rolnicy coraz częściej postrzegają rośliny strączkowe także jako tanie, dodatkowe źródło azotu (Szukała 2012). Dotyczy to w szczególności bobiku, gatunku który dzięki symbiozie $\mathrm{z}$ bakteriami brodawkowymi (Rhizobium leguminosarum) może wiązać bardzo duże ilości tego składnika pokarmowego.

Obok licznych zalet, takich jak: 1) duże możliwości plonotwórcze, 2) znaczna zawartość białka w nasionach, czy 3) doskonały przedplon dla wielu roślin uprawnych, wadą tego gatunku są stosunkowo niskie i zmienne w latach plony nasion (Kopiński i Matyka 2012). Wynika to między innymi ze znacznej wrażliwości tego gatunku na niekorzystny przebieg pogody, zwłaszcza niedobór wody (Podleśny 2009; Podleśny i Podleśna 2010) i występowanie wysokiej temperatury (Podleśny i Podleśna 2013) w okresie kwitnienia i zawiązywania strąków. Duże znaczenie ma także występowanie chorób grzybowych, które rozprzestrzeniają się bardzo szybko, zwłaszcza w warunkach zwiększonej wilgotności i wysokiej temperatury powietrza, powodując często obniżkę plonu i pogorszenie jego jakości (Kurowski i wsp. 2006), a w konsekwencji zmniejszenie opłacalności uprawy (Kulig i wsp. 2006). Szkodliwość chorób bobiku polega na ograniczaniu wzrostu i rozwoju roślin, a w skrajnych przypadkach także ich zamieraniu. Najczęściej występującymi chorobami bobiku są askochytoza (Ascochyta fabae Speg.), czekoladowa plamistość (Botrytis fabae Sardina) i rdza bobiku [Uromyces fabae (Pers). J. Schröt.] (Metodyka integrowanej ochrony i produkcji bobiku 2016). Ze względu na znaczne zróżnicowanie odmianowe $\mathrm{w}$ obrębie tego gatunku, można przypuszczać, że poszczególne odmiany bobiku będą $\mathrm{w}$ różnym stopniu podatne na porażenie przez patogeny. Ponadto z powodu niejednorodnych warunków klimatyczno-glebowych występujących na obszarze Polski, ważnym zagadnieniem jest określenie wrażliwości bobiku na choroby w różnych rejonach kraju.

Celem badań była ocena stopnia porażenia roślin bobiku przez patogeny $\mathrm{w}$ zależności od odmiany oraz przebiegu warunków pogodowych.

\section{Materiały i metody / Materials and methods}

Doświadczenia prowadzono w latach 2010-2012, w Stacjach Oceny Odmian Centralnego Ośrodka Badania Odmian Roślin Uprawnych (COBORU), w następujących województwach: 1 - opolskie, 2 - pomorskie, 3 - śląskie, 4 - podkarpackie, 5 - zachodniopomorskie, 6 - warminsko-mazurskie oraz 7 - dolnośląskie, w układzie losowanych bloków, w 4 powtórzeniach.

$\mathrm{W}$ badaniach uwzględniono 9 odmian bobiku, większość to odmiany o tradycyjnym typie wzrostu (Albus, Amulet, Bobas, Kasztelan, Leo, Olga i Sonet), a pozostałe - o zdeterminowanym wzroście (Granit i Optimal). Od- miany te były wpisane na Listę Odmian Roślin Rolniczych, a niektóre $\mathrm{z}$ nich wchodziły także w skład wzorca służącego do oceny odmian. Zakładana obsada roślin wynosiła dla odmian: Albus, Amulet, Bobas, Kasztelan, Leo, Olga i Sonet - 50 roślin $/ \mathrm{m}^{2}$, a dla odmian: Granit i Optimal - 70 roślin $/ \mathrm{m}^{2}$.

Doświadczenia prowadzono na glebach bardzo dobrych należących do następujących kompleksów przydatności rolniczej: pszenny bardzo dobry, pszenny dobry i żytni bardzo dobry. Przedplonem były najczęściej zboża, w nielicznych przypadkach bobik wysiewano po międzyplonach. Siew wykonano w końcu marca lub na początku kwietnia. Nawożenie azotem wynosiło $40 \mathrm{~kg} / \mathrm{ha}$, natomiast wielkość dawek fosforu i potasu ustalono na podstawie wyników analizy gleby. Przeciętne nawożenie wynosiło w kg/ha: $\mathrm{P}_{2} \mathrm{O}_{5}-60$ i $\mathrm{K}_{2} \mathrm{O}-80$. W okresie wegetacji prowadzono szczegółowe obserwacje wzrostu i rozwoju roślin oraz występowania chorób i szkodników. Ocenę zdrowotności bobiku wykonano w okresie zawiązywania pierwszych strąków (BBCH 70) na 25 roślinach z każdego poletka. Za porażenie roślin przyjęto stosunek liczby roślin porażonych do analizowanej liczby roślin wyrażony w $\%$. Zwalczanie chwastów dwuliściennych prowadzono metodą chemiczną stosując po siewie Afalon Dyspersyjny SC 450 SC (s. cz. linuron) w dawce 1,5-2,0 l/ha lub Linurex 500 SC (s. cz. linuron) w dawce 1,0-1,5 l/ha. Chwasty jednoliścienne zwalczano stosując preparat Fusilade Super 125 EC (s. cz. fluazyfop-P-butylowy) w dawce 2,5 l/ha. Przeciwko szkodnikom stosowano Karate Zeon 050 CS (s. cz. lambda-cyhalotryna) w dawce 0,15 l/ha lub Decis 2,5 EC (s. cz. deltametryna) w dawce 0,3 l/ha.

Przebieg warunków pogodowych charakteryzowano na podstawie ilości opadów i średniej dobowej temperatury powietrza. Powierzchnia poletek do zbioru wynosiła $16 \mathrm{~m}^{2}$. Po zbiorze określono plon nasion w przeliczeniu na $14 \%$ wilgotności.

Wyniki opracowano statystycznie wykorzystując program STATISTICA v. 13.1. Istotność różnic określano przy użyciu testu Tukeya, przyjmując poziom istotności $\alpha=0,05$.

Przebieg warunków pogodowych był zróżnicowany w latach i poszczególnych rejonach kraju (tab. 1). Stwierdzono również bardzo nierównomierny rozkład opadów. $\mathrm{W}$ wielu miejscowościach $\mathrm{w}$ okresie wegetacji bobiku występował niedobór lub znaczny nadmiar opadów, co miało duży wpływ na porażenie roślin przez patogeny oraz plonowanie bobiku.

W kwietniu 2010 roku stwierdzono duży niedobór opadów w województwach pomorskim i warmińskomazurskim oraz znacznie większą ilość opadów niż w pozostałych rejonach w województwach opolskim, śląskim i podkarpackim. Dużą ilość opadów odnotowano także w maju, w większości rejonów uprawy bobiku, w szczególności w województwach opolskim i śląskim. Z kolei w czerwcu odnotowano duży niedobór opadów w województwach pomorskim, dolnośląskim i zachodniopomorskim oraz dużą ich ilość w województwach opolskim i podkarpackim. Natomiast w lipcu szczególnie dużą ilość opadów odnotowano w województwach opolskim, pomorskim i podkarpackim. 
Tabela 1. Miesięczna suma opadów oraz średnie temperatury dobowe dla poszczególnych lokalizacji (2010-2012)

Table 1. Monthly sum of precipitation and mean day temperatures for individual locations (2010-2012)

\begin{tabular}{|c|c|c|c|c|c|c|c|c|c|c|}
\hline \multirow{2}{*}{$\begin{array}{l}\text { Województwo } \\
\text { Voivodeship }\end{array}$} & \multicolumn{5}{|c|}{ Opady - Precipitation [mm] } & \multicolumn{5}{|c|}{ Temperatura - Temperature $\left[{ }^{\circ} \mathrm{C}\right]$} \\
\hline & IV & $\mathrm{V}$ & VI & VII & VIII & IV & $\mathrm{V}$ & VI & VII & VIII \\
\hline \multicolumn{11}{|c|}{2010} \\
\hline Opolskie & 58,2 & 193,2 & 103,2 & 208,5 & 95,1 & 7,6 & 11,8 & 16,7 & 20,4 & 18,5 \\
\hline Pomorskie & 9,8 & 112,4 & 16,4 & 142,4 & 173,4 & 6,8 & 9,7 & 15,0 & 19,7 & 17,9 \\
\hline Śląskie & 54,3 & 214,6 & 61,2 & 21,0 & 96,4 & 8,7 & 12,4 & 17,1 & 19,7 & 18,6 \\
\hline Podkarpackie & 50,5 & 170,0 & 100,9 & 174,2 & 112,6 & 8,9 & 14,2 & 18,3 & 20,8 & 19,4 \\
\hline Zachodniopomorskie & 20,0 & 85,1 & 27,7 & 74,8 & 136,6 & 6,5 & 8,7 & 14,1 & 20,0 & 17,2 \\
\hline Warmińsko-Mazurskie & 16,9 & 153,0 & 80,8 & 64,1 & 122,2 & 7,3 & 11,9 & 15,8 & 20,5 & 18,9 \\
\hline Dolnośląskie & 34,5 & 118,1 & 32,4 & 109,7 & 112,4 & 9,2 & 12,7 & 17,9 & 21,1 & 19,1 \\
\hline \multicolumn{11}{|c|}{2011} \\
\hline Opolskie & 28,8 & 43,4 & 99,5 & 167,5 & 73,2 & 9,7 & 14,2 & 17,4 & 17,4 & 18,9 \\
\hline Pomorskie & 24,0 & 42,0 & 75,2 & 100,4 & 114,1 & 9,3 & 12,5 & 16,5 & 17,7 & 17,4 \\
\hline Śląskie & 21,4 & 57,4 & 42,8 & 111,2 & 32,0 & 10,4 & 13,6 & 18,3 & 17,6 & 19,1 \\
\hline Podkarpackie & 51,8 & 38,1 & 71,3 & 291,8 & 58,6 & 10,0 & 13,5 & 18,1 & 18,1 & 19,1 \\
\hline Zachodniopomorskie & 12,1 & 52,7 & 62,9 & 175,2 & 71,2 & 10,1 & 12,7 & 17,0 & 16,9 & 17,2 \\
\hline Warmińsko-Mazurskie & 26,6 & 40,9 & 63,2 & 203,4 & 72,9 & 9,2 & 12,7 & 17,0 & 17,6 & 17,9 \\
\hline Dolnośląskie & 32,7 & 56,3 & 48,2 & 206,3 & 37,6 & 11,5 & 13,7 & 18,7 & 18,5 & 19,4 \\
\hline \multicolumn{11}{|c|}{2012} \\
\hline Opolskie & 54,0 & 29,3 & 97,8 & 66,6 & 62,1 & 8,3 & 14,8 & 17,4 & 19,9 & 19,0 \\
\hline Pomorskie & 42,1 & 18,9 & 123,7 & 172,2 & 84,1 & 7,6 & 4,6 & 14,7 & 18,0 & 17,6 \\
\hline Śląskie & 64,8 & 35,2 & 70,7 & 50,9 & 49,4 & 9,0 & 15,9 & 17,8 & 20,9 & 20,0 \\
\hline Podkarpackie & 21,7 & 66,7 & 66,9 & 65,6 & 61,8 & 9,9 & 14,8 & 17,7 & 20,9 & 18,7 \\
\hline Zachodniopomorskie & 39,8 & 12,8 & 83,0 & 161,1 & 99,8 & 7,1 & 12,5 & 15,1 & 17,3 & 16,9 \\
\hline Warmińsko-Mazurskie & 79,5 & 48,5 & 97,6 & 106,0 & 94,2 & 7,8 & 13,3 & 15,1 & 18,9 & 17,3 \\
\hline Dolnośląskie & 33,1 & 34,7 & 81,7 & 101,6 & 61,6 & 9,6 & 15,4 & 17,3 & 20,2 & 19,4 \\
\hline
\end{tabular}

W okresie od kwietnia do czerwca 2011 roku odnotowano prawie we wszystkich województwach niedobór opadów, natomiast w lipcu - znaczny ich nadmiar. W miesiącach wiosennych 2012 roku wystąpił deficyt opadów, który był odczuwalny zwłaszcza w kwietniu w województwie podkarpackim oraz w maju w województwach pomorskim i zachodniopomorskim.

Stwierdzono również znaczne zróżnicowanie średnich temperatur dobowych pomiędzy województwami. W roku 2010 najwyższą średnią temperaturę dobową w kwietniu, maju i czerwcu odnotowano w województwach dolnośląskim, śląskim i podkarpackim, natomiast w lipcu średnia temperatura dobowa była podobna we wszystkich województwach. W 2011 roku najwyższą średnią temperaturę dobową w kwietniu, maju, czerwcu i lipcu zanotowano w województwie dolnośląskim. W roku 2012 najwyższą temperaturę $\mathrm{w}$ okresie od kwietnia do sierpnia odnotowano w województwach podkarpackim, dolnośląskim i śląskim.

\section{Wyniki i dyskusja / Results and discussion}

We wszystkich latach badań stwierdzono występowanie następujących chorób bobiku: askochytozy (A. fabae), czekoladowej plamistości (B. fabae) i rdzy bobiku (U. fabae) (rys. 1). W większym stopniu rośliny bobiku porażane były przez patogeny $A$. fabae i $B$. fabae, niż przez $U$. fabae. Oprócz wymienionych chorób sporadycznie występowały szara pleśń (Botrytis cinerea) i zgnilizna twardzikowa (Sclerotinia sclerotiorum), ale nie powodowały znaczących uszkodzeń roślin bobiku. Dlatego należy uznać, że spektrum chorób, które wystąpiły w prowadzonych badaniach nie było zbyt duże, bowiem bobik może być porażany także przez wiele innych patogenów (Metodyka integrowanej ochrony i produkcji bobiku 2016). Najprawdopodobniej, warunki pogodowe występujące w latach badań nie sprzyjały rozwojowi wielu chorób bobiku.

W latach 2010 i 2012 nasilenie chorób bobiku było większe niż w roku 2011, co spowodowane było większą ilością opadów i wyższą temperaturą w okresie kwitnienia i zawiązywania strąków. Takie warunki sprzyjają właśnie szybkiemu rozprzestrzenianiu się chorób grzybowych (Filoda i wsp. 2001).

Porażenie roślin przez choroby było bardzo różne w poszczególnych rejonach kraju (rys. 2). Największy stopień porażenia roślin bobiku przez patogeny $A$. fabae, $B$. fabae i $U$. fabae miał miejsce w województwach: 


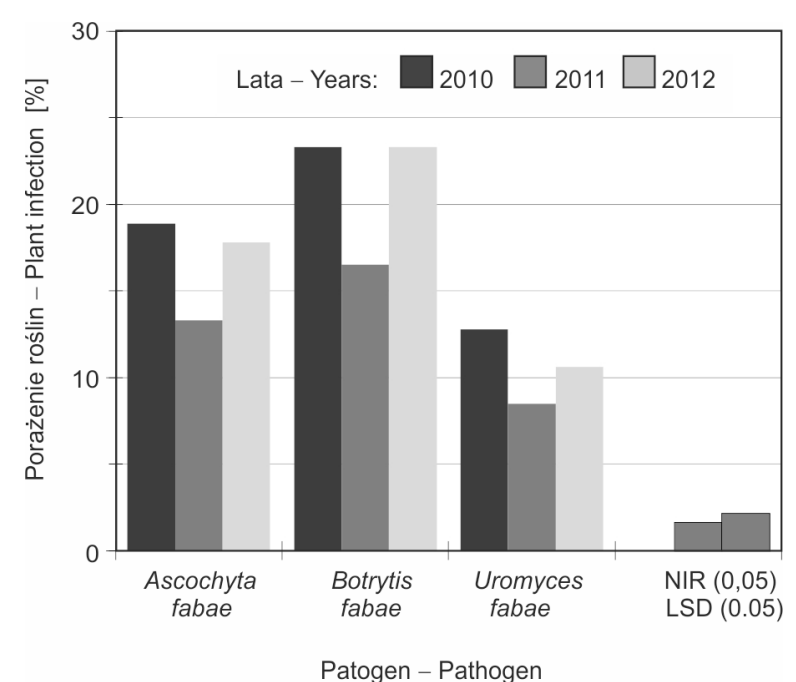

Rys. 1. Porażenie roślin bobiku przez patogeny (średnia dla wszystkich lokalizacji)

Fig. 1. Infection of faba bean plants by fungal pathogens (mean for all locations)

pomorskim, śląskim i zachodniopomorskim, znacznie mniejszy w województwach: opolskim i dolnośląskim, a najmniejszy w województwach: podkarpackim i warmińsko-mazurskim. Duże znaczenie, oprócz stopnia porażenia roślin, ma również szkodliwość chorób. Choroby, takie jak askochytoza i czekoladowa plamistość są bardziej groźne dla bobiku niż rdza (Metodyka integrowanej ochrony i produkcji bobiku 2016), dlatego mimo mniejszego zakresu wystepowania ich negatywne oddziaływanie na wzrost, rozwój i plonowanie bobiku było zdecydowanie większe.

Duży zakres występowania chorób był najczęściej powiązany $\mathrm{z}$ korzystnym dla ich rozwoju przebiegiem warunków pogodowych. Należy jednak podkreślić, że w wielu przypadkach o szybkim rozwoju patogena decydował w większym stopniu rozkład opadów niż ich ilość. Stąd w niektórych miejscowościach mimo dużej sumy opadów porażenie roślin było małe, ponieważ częstotliwość opadów była niewielka. Ponadto niekiedy nie stwierdzano ścisłej zależności między przebiegiem pogody a intensywnością rozwoju chorób grzybowych, co wskazuje na występowanie także innych czynników decydujących o stopniu porażenia roślin bobiku. Jednym z nich jest na przykład zdrowotność wysiewanego materiału nasiennego (Żuk-Gołaszewska i Fordoński 1997). Dlatego wysiew wysokiej jakości materiału siewnego jest jedną $\mathrm{z}$ podstawowych zasad integrowanej ochrony roślin (Dyrektywa 2009).

Porażenie odmian bobiku przez A. fabae kształtowało się w granicach 13,3-20\%, B. fabae w zakresie 15,6-27,8 oraz U. fabae 12,2-16,7\% (tab. 2). Średnio z 3 lat badań nieco większą odporność na patogeny $A$. fabae, $B$. fabae i U. fabae wykazywały odpowiednio odmiany: Olga i Sonet, Leo i Sonet oraz Leo, Olga, Optimal i Sonet. Natomiast nieco większą wrażliwość na $A$. fabae i $B$. fabae wykazano w odniesieniu do odmian: Granit i Optimal, a na U. fabae - w przypadku odmiany Kasztelan. Również Jarecki i Bobrecka-Jamro (2014) stwierdzili zróżnicowanie odmianowe bobiku w zakresie tolerancji na patogeny -

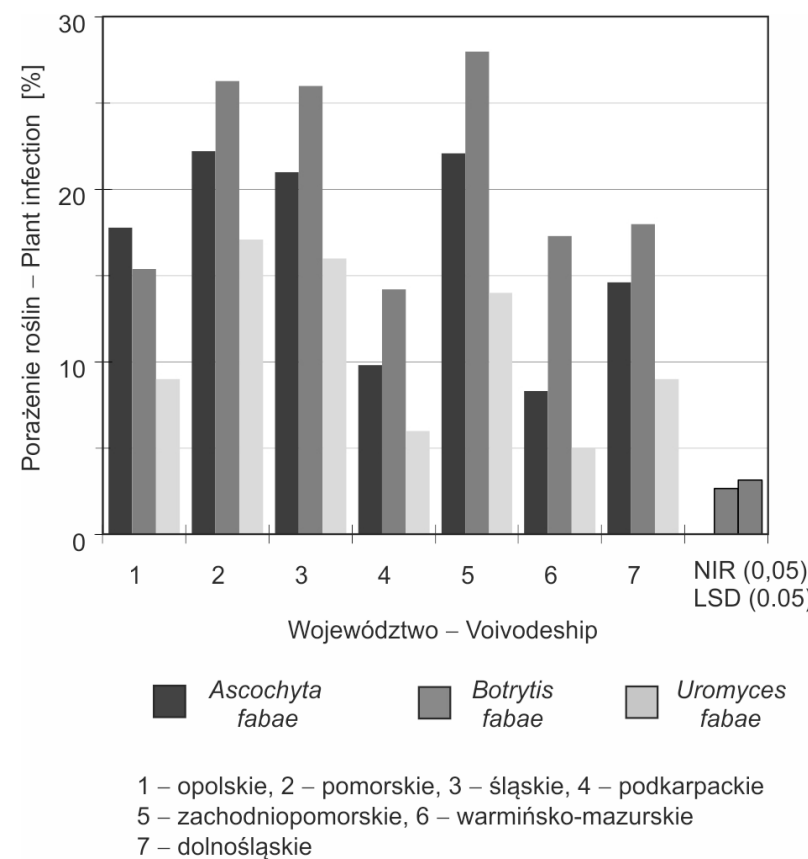

Rys. 2. Porażenie roślin bobiku przez patogeny w zależności od rejonu Polski (2010-2012)

Fig. 2. Infection of faba bean plants by fungal pathogens in dependence on region of Poland (2010-2012)

odmiana Amulet była odporniejsza na A. fabae niż odmiana Granit, co znalazło potwierdzenie także w niniejszych badaniach. Z kolei z badań COBORU wynika, że występują małe różnice między odmianami $\mathrm{w}$ zakresie ich podatności na porażenie przez wyżej wymienione patogeny. W przeprowadzonej w skali 9-stopniowej ocenie (9 - najbardziej odporna) wykazano, że odporność bobiku na patogeny jest średnia i wynosi od 6,3 do 7,7. W przypadku czekoladowej plamistości wartości wahały się w przedziale 6,3-7,1 (dla 6 badanych odmian), dla askochytozy bobiku było to $6,6-7,3$, a dla rdzy bobiku ocena wynosiła 7,3-7,8 (Osiecka 2015).

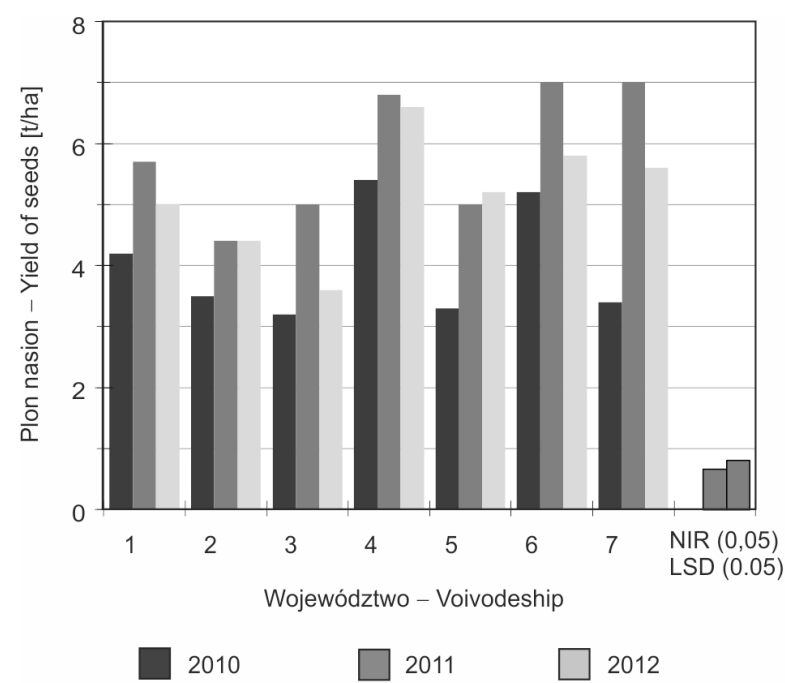

1 - opolskie, 2 - pomorskie, 3 - śląskie, 4 - podkarpackie

5 - zachodniopomorskie, 6 - warmińsko-mazurskie

7 - dolnośląskie

Rys. 3. Plonowanie bobiku (2010-2012)

Fig. 3. Yielding of faba bean (2010-2012) 
Tabela 2. Porażenie roślin bobiku przez patogeny (2010-2012) [\%]

Table 2. Infection of faba bean plants by pathogens (2010-2012) [\%]

\begin{tabular}{l|c|c|c|c}
\hline \multirow{2}{*}{$\begin{array}{c}\text { Odmiana } \\
\text { Cultivar }\end{array}$} & $\begin{array}{c}\text { Patogeny grzybowe - Fungal pathogens } \\
\text { askochytoza bobiku } \\
\text { ascochyta blight } \\
\text { Ascochyta fabae }\end{array}$ & $\begin{array}{c}\text { czekoladowa } \\
\text { plamistośc bobiku } \\
\text { chocolate spot } \\
\text { Botrytis fabae }\end{array}$ & $\begin{array}{c}\text { rdza bobiku } \\
\text { faba bean rust } \\
\text { Uromyces fabae }\end{array}$ & $\begin{array}{c}\text { Srednia } \\
\text { Mean }\end{array}$ \\
\hline Albus & 15,6 & 21,1 & 15,6 & 17,8 \\
\hline Amulet & 16,7 & 20,0 & 14,4 & 16,7 \\
\hline Bobas & 15,6 & 22,2 & 15,6 & 17,8 \\
\hline Granit & 20,0 & 27,8 & 14,4 & 17,7 \\
\hline Kasztelan & 16,7 & 20,0 & 12,2 & 15,6 \\
\hline Leo & 15,6 & 16,8 & 12,3 & 15,6 \\
\hline Olga & 13,4 & 20,0 & 12,3 & 20,0 \\
\hline Optimal & 20,0 & 25,6 & 12,2 & 13,3 \\
\hline Sonet & 13,3 & 15,6 & 14,4 & 17,8 \\
\hline Średnia - Mean & 16,7 & 21,1 & 2,14 & 1,48 \\
\hline NIR (0,05)- LSD (0.05) & 2,86 & 3,14 & & 14 \\
\hline
\end{tabular}

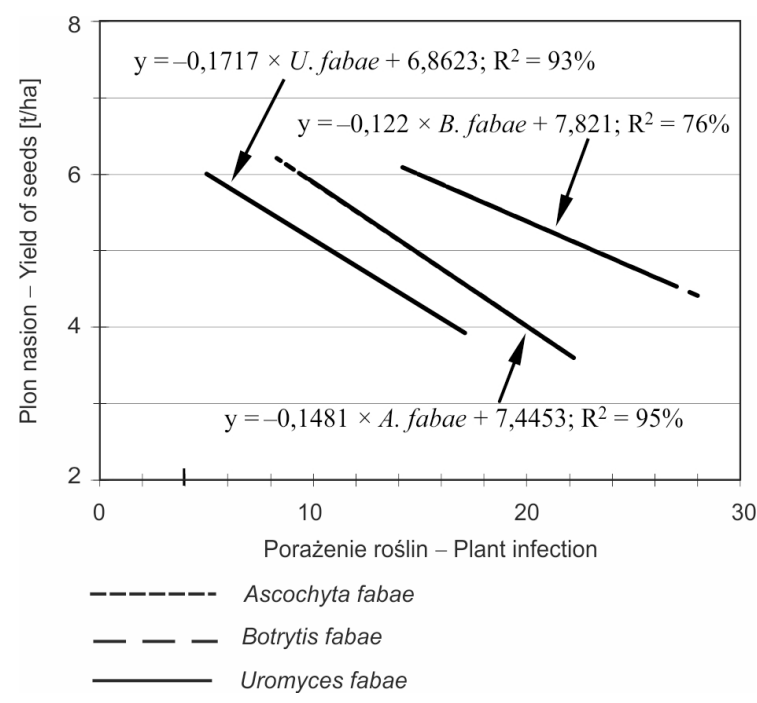

Rys. 4. Zależność między porażeniem nasion przez patogeny a plonowaniem bobiku

Fig. 4. Relationship between seed infection by pathogens and faba bean yielding

Największe plony nasion bobiku uzyskano w 2011 roku, nieco mniejsze w roku 2012 i najmniejsze w roku 2010 (rys. 3). We wszystkich latach badań najwyższe plony nasion bobiku zanotowano w województwie opolskim, a najmniejsze $\mathrm{w}$ województwach pomorskim i śląskim. W roku 2010 większość odmian plonowała na podobnym poziomie, przy czym - najlepiej plonowała odmiana Sonet (3,9 t/ha), a najsłabiej odmiany Olga $(3,3 \mathrm{t} / \mathrm{ha})$ i Optimal $(3,4 \mathrm{t} / \mathrm{ha})$, natomiast pozostałe odmiany plonowały $\mathrm{w}$ granicach 3,5-3,8 t/ha. W roku 2011 najlepiej plonującą była odmiana Bobas (5,7 t/ha), najsłabiej - odmiana Optimal $(5,1 \mathrm{t} / \mathrm{ha})$, a pozostałe odmiany plonowały $\mathrm{w}$ granicach 5,2-5,6 t/ha. Natomiast w roku 2012 najlepiej plonowała odmiana Amulet (5,1 t/ha), a najsłabiej Optimal (4,1 t/ha).
Analizując plonowanie odmian bobiku należy uznać, że większość z uwzględnionych w badaniach plonuje na zbliżonym poziomie i tylko niektóre $\mathrm{z}$ nich różnią się pod tym względem od wartości średniej obliczonej dla całej grupy.

Stwierdzono istotną zależność między porażeniem roślin przez patogeny a plonem nasion (rys. 4). Największą taką zależność wykazano w odniesieniu do askochytozy i rdzy bobiku, a znacznie mniejszą dla czekoladowej plamistości bobiku.

\section{Wnioski / Conclusions}

1. Askochytoza (A. fabae), czekoladowa plamistość (B. fabae) i rdza bobiku (U. fabae) były najczęściej występującymi chorobami bobiku.

2. Nasilenie występowania chorób zależało w dużym stopniu od przebiegu pogody, głównie ilości opadów i wartości średniej temperatury dobowej w okresie kwitnienia i zawiązywania strąków.

3. Nie stwierdzono bardzo dużego zróżnicowania w odporności odmian bobiku na choroby. Największe różnice wystąpiły w odniesieniu do $B$. fabae, mniejsze dla A. fabae, a najmniejsze dla U. fabae.

4. Plonowanie bobiku było zróżnicowane głównie w zależności od lat badań i lokalizacji doświadczenia. Większość uwzględnionych w badaniach odmian plonowała na zbliżonym poziomie.

Praca wykonana w ramach realizacji zadania 2.3 Programu Wieloletniego Instytutu Uprawy Nawożenia i Gleboznawstwa - Państwowego Instytutu Badawczego w Puławach pt. „Wspieranie działań w zakresie ochrony i racjonalnego wykorzystania rolniczej przestrzeni produkcyjnej w Polsce oraz kształtowania jakości surowców roślinnych na lata 2016-2020”. 


\section{Literatura / References}

Dyrektywa Parlamentu Europejskiego i Rady 2009/128/WE z dnia 21 października 2009 r. ustanawiająca ramy wspólnotowego działania na rzecz zrównoważonego stosowania pestycydów (Dz. Urz. UE L 309/71 z dnia 24.11.2009): 71-86.

Filoda G., Horoszkiewicz J., Jańczak C. 2001. Występowanie i szkodliwość antraknozy na łubinie żółtym w różnych warunkach pogodowych 1999 i 2000 roku. [Occurence and pathogenity of yellow lupin anthracnose in different weather conditions in 1999 and 2000]. Progress in Plant Protection/Postępy w Ochronie Roślin 41 (1): 278-285.

Jarecki W., Bobrecka-Jamro D. 2014. Wpływ dawki startowej azotu oraz dokarmiania dolistnego na wskaźnik LAI oraz porażenie przez patogeny grzybowe dwóch morfotypów bobiku. [Influence of initial dose of nitrogen and foliar nutrition on LAI index and infection of fungal pathogens of two morphotypes of field bean]. Progress in Plant Protection/Postępy w Ochronie Roślin 54 (4): $430-436$. DOI: http://dx.doi.org/10.14199/ppp-2014-073.

Jerzak M.A. 2014. Możliwości restytucji rynku rodzimych roślin strączkowych na cele paszowe w Polsce. Roczniki Naukowe XVI (3): 104-109.

Kopiński J., Matyka M. 2012. Regionalne zróżnicowanie produkcji i opłacalności upraw roślin strączkowych pastewnych na nasiona w Polsce. Polish Journal of Agronomy 10: 9-15.

Kulig B., Ropek D., Dłużniewska J. 2006. Efektywność ekonomiczna i produkcyjna zabiegów ochrony roślin w uprawie zróżnicowanych morfologicznie odmian bobiku. Pamiętnik Puławski 142: 251-261.

Kurowski T.P., Hruszka M., Bogucka B. 2006. Zdrowotność bobiku w zależności od jego udziału w płodozmianie i stosowania wsiewki gorczycy sarepskiej. [Sanitary state of field bean as depended upon its proportion in crop rotation and the use of chinese mustard as a companion crop]. Progress in Plant Protection/Postępy w Ochronie Roślin 46 (2): 24-30.

Metodyka integrowanej ochrony i produkcji bobiku. 2016. Praca zbiorowa pod redakcją P. Strażyńskiego i M. Mrówczyńskiego. Instytut Ochrony Roślin - Państwowy Instytut Badawczy, Poznań: 47-64.

Osiecka A. 2015. Lista opisowa odmian. Rośliny rolnicze. Bobik. Centralny Ośrodek Badania Odmian Roślin Uprawnych, Słupia Wielka: $107-111$.

Osiecka A. 2016. Lista opisowa odmian. Rośliny rolnicze. Bobik. Centralny Ośrodek Badania Odmian Roślin Uprawnych, Słupia Wielka: $115-120$.

Podleśny J. 2009. Wpływ ilości i rozkładu opadów w okresie wegetacji na wzrost, rozwój i plonowanie samokończących i tradycyjnych odmian bobiku. Acta Agrophysica 14 (2) [171]: 413-425.

Podleśny J., Podleśna A. 2010. The estimation of water demands of a determinate and traditional cultivars of faba bean (Vicia faba L.). Polish Journal of Agronomy 2: 44-49.

Podleśny J., Podleśna A. 2013. Effect of high temperature in the flowering period on growth, development and yielding of faba bean (Vicia faba L. spp. minor). [Wpływ wysokiej temperatury w okresie kwitnienia na wzrost, rozwój i plonowanie bobiku (Vicia faba L. spp. minor)]. Ecological Chemistry and Engineering A. 20 (1): 71-76. DOI: 10.2428/ecea.2013.20(01)008.

Szukała J. 2012. Nowe trendy w agrotechnice roślin strączkowych i sposoby zwiększania opłacalności uprawy. Materiały Komisji Rolnictwa i Rozwoju Wsi, Warszawa, 45: 8-10.

Żuk-Gołaszewska K., Fordoński G. 1997. Produktywność i zdrowotność bobiku w zależności od jakości materiału siewnego i terminu stosowania fungicydów. Zeszyty Problemowe Postępów Nauk Rolniczych 439: 55-61. 